J. Perinat. Med. 6 (1977) 260

\section{Neonatal head shape after delivery: An index of molding}

\author{
Timothy J. Kriewall, Stanley J. Stys, Gregg K. McPherson
}

University of Michigan, Women's Hospital, Ann Arbor, USA
Molding at parturition, as perceived subjectively, ranges from no reshaping to marked distortion of the infant's head. While clinicians easily recognize the highly molded head, there are no criteria for quantitating the degree of molding. The purpose of the present study is to describe quantitatively neonatal skull molding and the restitution of the newborn's skull from the molded state during the early neonatal period.

\section{Literature review}

In 1907, STUMPF [13] studied the restitution of molding in the neonatal period. Measurements of two head circumferences of vaginally delivered infants were compared to control infants delivered by cesarean section, assumed to be unmolded. He concluded that the plane of the suboccipitobregmatic diameter was the presenting plane in labor, and that molding was a result of interaction of the head with soft tissues rather than the bony pelvis. Both the suboccipitobregmatic and suboccipitofrontal diameters increased during restitution.

HollaND [5], in 1922, described cranial stress during labor and the relationship of excessive stress to tentorial tears and subdural cerebral hemorrhage. He wrote that tension of the intracranial septa are inevitable as the head undergoes molding. Molding was described as ,an alteration in the position, absolute and relative, and curvature of the cranial bones."

Two years later GreENwood [4] disputed HollaND's description of the direction of length-

\section{Curriculum vitae}

Dr. TIMOTHY J. KRIEWALL was born in 1945. He received a B.S.E. in electrical engineering from the University of Michigan in 1967 and a M.S.E. in electrical engineering from Stanford University in 1968. After working in industrial research for three years, he returned to the University of Michigan to earn a Ph.D. in biomedical engineering in 1974. He is currently an assistant professor at The University of Michigan's Medical School in the Department of Obstetrics and Gynecology.

ening of the molded head stating that it was anteroposterior rather than vertical. Furthermore, restitution of molding in heads which presented occiput anterior was noted to be faster than in those which presented occiput posterior.

The first radiologic study of molding was reported in 1942, by MoLor [8]. Skull films taken immediately after birth compared vaginal deliveries to cesarean sections. A compression binder was also used to simulate the forces of parturition in order to make before and after comparisons. Moloy described an increase in the maxillary-vertical diameter caused by flattening and/or elevation of the parietal bones. In contrast to Holland, he also felt the occipital plate elevated.

BAXTER [1] in the same year used autopsy specimens to describe mechanisms of molding. He 
agreed with many of MoLoY's observations and concluded that vertical elevation and flattening of the parietals are limited mechanisms affording little margin before compression of cranial contents begins.

In 1958, BORELL and FERNSTROM [2] performed an intrapartum radiographic study and discovered that during labor the parietal bones rotate outwards and are displaced upwards resulting in an increase of the biparietal diameter of as much as $10 \mathrm{~mm}$. Like STUMPF fifty years before, they concluded that molding of the head is produced by maternal soft tissues rather than by the bony pelvis.

At the same time LiNDGREN's studies [6] brought him to the same conclusion regarding the structures causing molding of the fetal head. He made continuous recordings during labor of amniotic pressures and pressures exerted on the fetal head by the uterine wall. Pressures on the greatest circumference of the fetal head were noted to be several times greater than amniotic pressures during both uterine contractions and the resting phase.

In 1968, ScHWARCZ et al [12] confirmed LINDGREN's observation that pressure on the equator of the fetal head during uterine contractions is greater than amniotic fluid pressure. They also noted that cephalic compression during uterine contractions could lead to transient cerebral ischemia resulting in cardiac decelerations.

In the same year WiLLERMAN [14] reported two studies on intellectual differences in children born left occiput anterior and right occiput anterior. Children delivered from right occiput anterior had lower performance IQ than verbal IQ scores. The children delivered from left occiput anterior had no difference in performance or verbal IQ scores. Assuming that the hemispheres of the brain have different capacities for verbal or performance functions, these studies imply that impairment of verbal or performance function might occur as a result of the presentation of the head during labor.

The subjective impressions of molding that clinicians use are understandable considering the literature just reviewed. These studies are widely spaced in time and use several vastly different methods. The qualitative mechanisms of fetal skull molding are still only poorly defined, and quantitative measurements of molding have been nonexistent. There- fore, this study was undertaken to devise a quantitative measure of molding.

\section{Methods}

Thirty-eight infants delivered at the University of Michigan Medical Center were studied for molding. The study group is representative of the patient population delivered at this medical center.

Twenty-three infants were delivered vaginally from vertex presentations. Fifteen infants were delivered by elective cesarean section before the onset of labor; two of these were breech presentations, and the others vertex. Three infants weighed less than 2500 grams, four greater than $\mathbf{4 0 0 0}$ grams. Fifteen mothers were primiparas, twenty-three multiparous. The age range of the mothers was 14-35 years.

Measurements of each infant's skull were made with obstetrical calipers. The distance was measured to the nearest millimeter. Measurements of the biparietal, bitemporal, suboccipitobregmatic, suboccipitofrontal, occipitofrontal, submentobregmatic and mentovertical diameters were made within the first hour after birth and repeated at $24,48,72$ hours of age.

A second group of ten infants was studied for measurement precision and observer influence. The two groups of infants were similarly composed.

The biparietal, suboccipitofrontal and mentovertical diameters were used to describe an ellipsoid which approximates the volume of the infant's head. The parameter "curvature" from analytical geometry was used to derive a molding index. Curvature defines the amount of change in the angle of a tangent to a curve for an incremental change in the arc length of the curve. To define curvature in a three-dimensional sense, the geometric mean was taken for the curvature in the two planes defined by the biparietal and mentovertical diameters and by the suboccipitofrontal and mentovertical diameters. The molding index was made more sensitive by taking the product of the geometric mean of the curvatures and the mentovertical diameter. Thus, the molding index used in this study is defined by the following equation. 


\section{M.I. = \\ (mentovertical diameter) ${ }^{2}$ \\ (biparietal diameter) $\times$ (suboccipitofrontal diameter)}

\section{Results}

\subsection{Measurement precision}

The means of the seven diameters for the ten infants studied for observer influence were calculated for each observer and compared. The correlation of the individual measurements of the two observers was also calculated for each diameter. The correlation coefficient of individual measurements ranged between 0.81 and 0.99 for all diameters and the standard error was between 0.10 and $0.19 \mathrm{~cm}$ except the submentobregmatic.

\section{i 3.2 Restitution of molding}

Within the tolerance of the measurement variabilities, only the biparietal, suboccipitofrontal and mentovertical diameters were noted to change significantly over the first three days postpartum in the molding study group. The infants were stratified according to whether the mother labored (delivered vaginally or by elective cesarean section). Tab. I summarizes the means of the diameters for the two groups.
The data indicate that, in infants born as a result of labor, the biparietal and mentovertical diameters decrease $(p<.01)$ during 'restitution; the suboccipitofrontal diameter increases $(p<.01)$. In the group of infants delivered by elective cesarean section, the biparietal diameter also decreases ( $\mathrm{p}<.01)$ during restitution, but the mentovertical diameter increases $(p<.01)$ while the suboccipitofrontal diameter remains unchanged.

\subsection{The molding index}

The molding index (M.I.) was calculated for each group of infants. For the infants born after labor, the M.I. ranged from 1.56 to 2.31 , having a mean of 2.00 and a standard deviation of 0.22 . For the infants born before labor, the M.I. ranged from 1.44 to 2.12 , having a mean of 1.68 and a standard deviation of 0.19 . The difference in the means was highly significant $(p<.0005)$ (Tab. II).

Regression analyses of the molding index and the length of the first stage of labor, the length of the second stage of labor and the combined length of the first and second stages were carried out (Tab. III). There was statistically significant correlation only between the length of the second stage of labor and the M.I. $(r=0.53)$.

Tab. I. Skull measurements in early neonatal period compared by labor. The paired significance shows the change in the repeated measurements among the same groups and the strata significance compares the measurements made at the same relative time between the two groups.

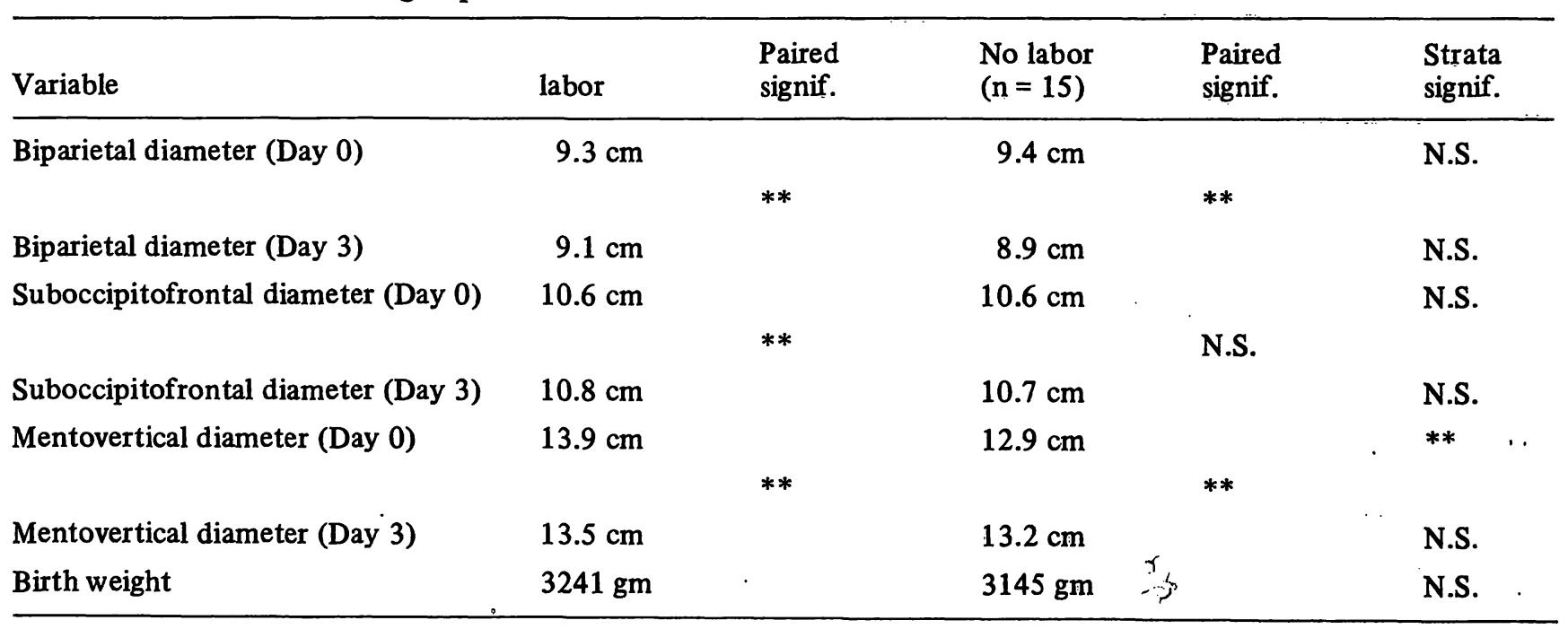

N.S. - Not statistically significant

** $-\mathrm{p}<.01$ 
Tab. II. Comparison of molding index stratified by labor.

\begin{tabular}{llllll}
\hline Variable & $\begin{array}{l}\text { Yes } \\
(\mathrm{n}=23)\end{array}$ & $\begin{array}{l}\text { Paired } \\
\text { signif. }\end{array}$ & $\begin{array}{l}\text { No } \\
(\mathrm{n}=15)\end{array}$ & $\begin{array}{l}\text { Paired } \\
\text { signif. }\end{array}$ & $\begin{array}{l}\text { Strata } \\
\text { signif. }\end{array}$ \\
\hline Molding index (Day 0) & 2.00 & & 1.68 & $* *$ & $* *$ \\
Molding index (Day 3) & 1.86 & $* *$ & 1.82 & $* *$ & N.S. \\
\hline
\end{tabular}

N.S. - Not statistically significant

$* *-\mathrm{p}<.01$

The molding indexes were comparedforprimiparous and multiparous mothers whose infants were born vaginally. There were ten primiparous and eleven multiparous mothers. The mean M.I. for infants of primiparous mothers was 2.07 with a standard deviation of 0.16 . The mean M.I. for infants of multiparous mothers was 1.88 with a standard deviation of 0.23 . The difference was statistically significant $(p<0.05)$.

The M.I. was not correlated to infant weight in either group ( $r=0.15$ and -0.24 for infants of laboring and non-laboring mothers, respectively).

Tab. III. Regression analysis of length of labor and molding index.

\begin{tabular}{ll}
\hline Dependent Variable & Correlation Coefficient (r) \\
\hline 1 st stage of labor & 0.21 (N.S.) \\
2nd stage of labor & $0.53(*)$ \\
Combined 1 st \& 2 nd stage & 0.30 (N.S.) \\
of labor & \\
\hline
\end{tabular}

N.S. - Not statistically significant

$* *-\mathrm{p}<.05$

The molding indexes were compared for infants born after labor stratified by position. Occiput anterior presentations $(n=16)$ were compared with the pooled values of occiput transverse $(n=5)$ and occiput posterior $(n=2)$ presentations. The mean M.I. for OA presentations was 1.93 having a standard deviation of 0.20 . The mean M.I. for the OT and OP group was 2.05 having a standard deviation of 0.24 . The difference is not statistically different.

\section{Discussion}

\subsection{Observations on measurement precision}

Based on the means, variances and correlation between the two observers, the observers make essentially the same measurements for the biparietal, suboccipitofrontal and occipitofrontal diameters. The standarderror of measurement for the biparietal diameter was commensurate with ultrasonic cephalometry as reported by others $[7,10]$. The observers do not make the same measurements consistently for the bregmatic diameters. This reflects the difficulty in defining landmarks within the bregma and in touching the bregma with the calipers without deforming the soft tissue.

\subsection{Observations on the restitution of molding}

In spite of the dramatic visual changes that often take place in the shape of the infant's head after delivery, only three of the seven diameters measured changed significantly. The four diameters which did not change significantly during restitution may contribute to the molding and restitution process, but their effects are either small or simply obscured by the inability to make precise measurements with the methods in this study.

Of the three remaining diameters, significant changesoccur in the same direction for the biparietal diameter for both groups of infants stratified by exposure to labor. The suboccipitofrontal diameter increased during restitution in both groups, but not significantly in the group without labor. These results corroborate the findings only recently reported by DESouzA et al. [3]. The direction of change for the mentovertical diameter was different for the two groups, decreasing during restitution 
for infants delivered vaginally and increasing in infants delivered before labor.

If restitutional changes are opposite in direction to molding changes, then, for the fetus delivered from the vertex position as a result of labor, molding increases the biparietal and mentovertical diameters while decreasing the suboccipitofrontal diameter. STUMPF [13] felt that the plane of the suboccipitobregmatic diameter presents most often during labor. If this plane's dimensions are to be minimized, the sagittal diameter, approximated by the suboccipitofrontal diameter, should decrease while the transverse diameter, approximated by the biparietal diameter, should increase. BORELL and FERNSTROM [2] described changes of this type in their intrapartum radiographic study. Compression forces on the presenting suboccipitobregmatic plane would lead to mentovertical diameter lengthening by displacement of parietal, frontal and occipital bones as described by BAXTER [1].

The changes which occur in the group of infants delivered before exposure to labor indicate that this group is not an ideal control group as several authors have assumed $[9,13]$. Some degree of molding occurs merely with positioning of the fetal head within the uterus prior to labor. Restitutional changes in the biparietal and suboccipitofrontal diameters are in the same direction as in infants delivered vaginally, although suboccipitofrontal diameter changes are not significantly different during restitution.

Mentovertical diameter changes are opposite between the two groups of infants. The continuing repetitive BRAXTON-HICKS contractions throughout pregnancy may be a previously unrecognized factor involved in the change of head shape in those infants born before labor. Environmental differences of intraamniotic and extrauterine life may be another factor involved in the dynamics of head shaping of newborns.

\section{Summary}

The purpose of this study is to describe quantitatively the restitution of the newborn's skull from the molded state during the early neonatal period. Measurements of seven skull diameters of thirty-eight infants were made within the first hour after birth and repeated at 24, 48 and 72
Since the biparietal, suboccipitofrontal and mentovertical diameters change dramatically in neonates regardless of their exposure or lack of exposure to labor, a quantitative index of molding based on these three diameters might indicate the dynamics of the process for both groups.

\subsection{The molding index}

The molding index as defined in the text was shown to reflect, on the whole, the shape of the infant's heads. However, due to the overlap in the individual values, one cannot infer from this single index whether or not the infant has a molded head.

A comparison of the two groups indicates that the heads of infants born before labor are as distorted as those born after labor, the difference being in the direction of the shape change. Those infants born after labor have more oblong heads while those born before labor have rounder heads. After the three days of postpartum restitution, the head shapes of both groups are the same (Tab. II). The fact that the heads of infants born before labor are molded points to the error in such statements as ,a certain amount of molding is present in every baby's head, except in those born by elective cesarean section" (MYLES [9]).

A statistically significant correlation between the molding index and the length of the second stage of labor may indicate that the greater the disproportion between the fetal head and maternal pelvis, the longer the second stage of labor. This assumes a larger disproportion produces a proportionately higher molding index. However, since the square of the correlation coefficient accounts for the proportion of variation of one variable explained by a regression on the other variable, (REMINGTON and SCHORK [11]) it appears that disproportion is not the major determinant for the length of labor's second stage $\left(\mathrm{r}^{2}=0.28\right)$.

hours of age. The measurements were made with obstetrical calipers. The measurement precision was tested on an independent study group, and found to be comparable to ultrasonic cephalometry; the standard error of measurement was less than 0.19 centimeters for all the diameters critical 
to the study. Within this tolerance of measurement variability, only the biparietal, suboccipitofrontal and mentovertical diameters were noted to change significantly over the first three days postpartum. The infants were stratified according to whether the mother labored. For infants born after labor $(n=23)$, the biparietal and mentovertical diameters decrease $(\mathrm{p}<.01)$ during restitution, but the suboccipitofrontal diameter increases $(p<.01)$. For infants born by elective cesarean section, the biparietal diameter also decreases $(p<.01)$ during restitution, but the mentovertical diameter increases $(p<.01)$. The suboccipitofrontal diameter remains unchanged (Tab. I). The changes which occur in the group of infants delivered before exposure to labor indicate that this group is not an ideal control group as several authors have assumed $[9,13]$. The infants from the two groups start at birth with heads distorted in opposite directions about the long axis, but subsequently undergo head reshaping toward a common end point secondary to restitutional and environmental forces.

To quantitate the degree of head molding as a consequence of the birth process, an index of molding was derived. The index of molding is defined as the square of the mento- vertical diameter divided by the product of the biparietal and suboccipitofrontal diameters. The mean molding index (M.I.) of the infants born after labor $(n=23)$ was 2.00 with a standard deviation of 0.22 . The mean and standard deviation of the infants born before labor $(n=15)$ was 1.68 and 0.19 , respectively, The difference in the means of the two groups was highly significant $(p<.0005)$ (Tab. II). However, after three days of postpartum restitution, there was no difference in the M.I. of the two groups. A regression analysis of the molding index on the length of the first, second and combined stages of labor showed that a statistically significant correlation $(r=53)$ existed only for the second stage of labor $(p<.05)$ (Tab. III). The mean M.I. of infants born from laboring primiparous mothers $(n=10)$ was significantly greater than the M.I. of infants born from laboring multiparous mothers $(n=11)$. The M.I. was not correlated with infant weight.

A comparison of the two groups that were stratified according to labor indicates that the heads of infants born before labor are just as misshapened as those that are born after labor, the difference being in the direction of the shape change.

Keywords: Caput succedaneum, fetal skull, head diameters, labor, molding index, neonatal skull, parturition.

\section{Zusammenfassung}

Die neonatale Kopfform nach der Geburt: ein Verformungsindex

Ziel dieser Studie war es, die Wiederherstellung der Kopfform des Neugeborenen während der frühen Neonatalperiode quantitativ $\mathrm{zu}$ beschreiben. 7 Kopfdurchmesser wurden bei 38 Kindern innerhalb der 1 . Stunde nach der Geburt gemessen und die Messungen nach 24, 48 und 72 Lebensstunden wiederholt. Die Messungen wurden mit geburtshilflichen Zirkeln durchgeführt. Die Meßgenauigkeit ist in einer unabhängigen Studie geprüft worden, wobei herauskam, daß sie mit der Ultraschallkephalometrie vergleichbar ist; die Standardabweichung der Mittelwerte betrug weniger als $0,19 \mathrm{~cm}$ für alle in dieser Studie wichtigen Durchmesser. Innerhalb dieser Meßtoleranz veränderten sich nur der biparietale, subokzipitofrontale und mentovertikale Durchmesser innerhalb der ersten 3 postpartalen Tage signifikant. Die Kinder wurden in Gruppen eingeteilt, je nachdem ob die Mutter Wehen hatte oder nicht. Bei Neugeborenen, die vaginal nach Wehentätigkeit geboren worden waren $(n=23)$ nahm der biparietale und mentovertikale Durchmesser während der Restitutionsphase $\mathrm{ab}(\mathrm{p}<0.01)$, der subokzipitofrontale Durchmesser nahm jedoch zu ( $p<0.01)$. Bei Kindern, die durch elektive Schnittentbindung zur Welt gekommen waren, nahm der biparietale Durchmesser ebenfalls ab ( $p<0,01$ ) während der Rückbildungsperiode, der mentovertikale Durchmesser jedoch zu $(\mathrm{p}<0,01)$. Der subokzipitofrontale Durchmesser blieb unverändert (Tab. I). Die Durchmesserveränderungen, die in der Gruppe von Kindern auftraten, die vor Einsetzen der Wehentätigkeit geboren worden waren, weisen darauf hin, daß diese Gruppe im Gegensatz zur Meinung verschiedener Autoren $[9,13]$ kein ideales Kontrollkollektiv darstellt. Die Kinder beider Untersuchungsgruppen haben nach der Geburt einen
Kopf, der um die Längsachse in Gegenrichtung geformt ist, in der Folgezeit dann jedoch auf einen gemeinsamen Endzustand hin sich verformt, unabhängig von Restitutions- und Umweltkräften.

Um das Ausmaß der durch den Geburtsprozeß ausgelösten Schädelverformung zu bestimmen, wurde ein Verformungsindex entwickelt. Der Index ist definiert durch das Quadrat des mentovertikalen Durchmessers dividiert durch das Produkt aus biparietalem und subokzipitofrontalem Durchmesser. Der mittlere Verformungsindex, der nach Wehentätigkeit geborenen Kinder $(n=23)$ betrug 2,00 mit einer Standardabweichung von 0,22 . Mittelwert und Standardabweichung der Kinder, die vor regulärer Wehentätigkeit geboren wurden $(n=15)$ betrug 1,68 und 0,19 . Die Differenz der Mittelwerte beider Gruppen war statistisch hochsignifikant $(p<.0005)$ (Tab. II). Nach einer dreitägigen postpartalen Restitutionsphase fand sich jedoch keine Differenz mehr im Verformungsindex beider Gruppen. Eine Regressionsanalyse des Verformungsindex mit der Dauer der Eröffnungs- und Austreibungsperiode sowie mit einer Kombination beider Abschnitte ergab, daß nur für die Austreibungsperiode eine statistisch signifikante Korrelation ( $r=0,53)$ besteht (Tab. III). Der mittlere Schädelverformungsindex von Neugeborenen, die von erstgebärenden Frauen nach Wehentätigkeit $(n=10)$ geboren worden waren, war signifikant größer als jener von Neugeborenen mehrgebärender Mütter $(n=11)$. Der Verformungsindex war mit dem Kindsgewicht nicht korreliert.

Ein Vergleich der Köpfe in den beiden Gruppen, die entsprechend der Wehentätigkeit gebildet wurden zeigte, daß die Köpfe von Kindern, die vor Wehentätigkeit geboren wurden, ebenso verformt sind wie jene, die nach Wehentätigkeit zur Welt kamen.

Schlüsselwörter: Caput succedaneum, fetaler Kopf, Geburt, Kopfdurchmesser, neonataler Kopf, Verformungsindex, Wehen. 
Résumé

Forme crânienne néonatale après l'accouchement: Index de déformation

Le présent article se propose de décrire quantitativement la restitution du crâne déformé du nouveau-né pendant la première période néonatale. Pour cela, nous avons mesuré sept diamètres crâniens de 38 bébés durant la première heure suivant la naissance, puis 24,48 et 72 heures après la naissance. Ces mesures ont été réalisées à l'aide de calipers obstétriques. La précision en a été testée sur un groupe d'étude indépendant et trouvée comparable à la céphalométrie ultrasonique; l'erreur type de mesure a été inférieure à $0.19 \mathrm{~cm}$ pour tous les diamètres soumis à l'étude. Compte tenu de cette variation tolérée de mesure, seuls les diamètres bipariétal, suboccipitofrontal et mentovertical ont montré un changement important pendant les trois premiers jours post partum. Les bébés ont été stratifiés selon que la mère a été en travail ou non. Pour les enfants nés après le travail $(n=23)$, nous avons relevé une baisse des diamètres bipariétal et mentovertical $(\mathrm{p}<.01)$ pendant la restitution, mais une augmentation du diamètre suboccipitofrontal $(p<.01)$. Pour les enfants nés par césarienne élective, le diamètre bipariétal décroît aussi $(\mathrm{p}<.01)$ pendant la restitution, tandis que le diamètre mentovertical augmente $(p<.01)$ et que le diamètre suboccipitofrontal reste inchangé (Tab. I). Les changements observés dans le groupe desenfantsnés avant l'exposition au travail prouvent que ce groupe ne remplit pas des conditions de contrôle aussi idéales que l'ont prétendu divers auteurs $[9,13]$. Les enfants des deux groupes ont d'abord à la naissance des têtes déformées dans des directions opposées sur l'axe long, mais ils subissent ensuite une «reformation» de la tête vers un point terminal commun secondaire aux forces restitutionnelles et environnantes.

Afin de déterminer quantitativement le degré de déformation crânienne conséquente à la parturition, nous avons dérivé un index de déformation (molding index: M.I.), défini comme le carré du diamètre mentovertical divisé par le produit des diamètres bipariétal et suboccipitofrontal. L'index de déformation moyen des enfants nés après le travail $(n=23)$ a été de 2.00 avec une déviation type de 0.22 . Les déviations moyenne et type des enfants nés avant le travail $(n=15)$ ont été respectivement de 1.68 et 0.19 . La différence dañs les moyennes des deux groupes a été très significative $(\mathrm{p}<.0005)$. (Tab. II). Cependant, après 3 jours de rèstitution post partum, nous n'avons observé aucune différence dans le M.I. des deux groupes. Une analyse régressive de l'index de déformation sur la longueur des phases première, seconde et combinée du travail a montré qu'il n'existait une corrélation d'importance statistique $(r=53)$ que pour la seconde phase du travail ( $p<.05)$. (Tab. III). Le M.I. moyen des enfants nés de mères primipares en travail $(n=10)$ a été beaucoup plus grand que le M.I. des enfants nés de mères multipares en travail $(n=11)$. Nous n'avons relevé aucune corrélation entre le M.I. et le poids des bébés.

Une comparaison des deux groupes qui ont été stratifiés dépendamment du travail indique que les têtes des bébés nés avant le travail sont tout aussi déformées que chez les bébés nés après le travail, là différence portant sur la direction prise par la déformation.

Mots-clés: Caput succedaneum, crâne foetal, crâne néonatal, diamètres de la tête, index de déformation, parturition.

Acknowledgments: The authors wish to thank Prof. M. ANTHONY SCHORK and Ms. SANDY STEINHORN for their assistance in the statistical analysis.

This work was made possible through the University of Michigan's Medical School Fund for Computing.

Bibliography

[1] BAXTER, J.: Moulding of the fetal head. J. Obstet. Gynaec. Brit. Emp. 53 (1946) 212

[2] BORELL, U., I. FERNSTROM: Die Umformung des kindlichen Kopfes während normaler Entbindung in regelrechter Hinterhauptslage und bei engem Becken. Geburtsh. u. Frauenheilk. 18 (1958) 1156

[3] DESOUZA, S. W., J. ROSS, R. D. G. MILNER: Alterations in head shape of newborn infants after caesarean section or vaginal delivery. Arch. Dis. Child. 51 (1976) 624

[4] GREENWOOD, W. O.: Moulding of the foetal head and its consequences. J. Obstet. Gynaec. Brit. Emp. 31 (19.24) 611

[5] HOLLAND, E.: Cranial stress in the foetus during labor and the effects of excessive stress on the intracranial contents. J. Obstet. Gynaec. Brit. Emp. 29 (1922) 549

[6] LINDGREN, L.: The causes of foetal head moulding in labor. Acta Obstet. Gynec. Scand. 39 (1960) 46
[7] LUND, R. M., T. CHARD: Reproducibility of measurement of fetal biparietal diameter by ultrasonic cephalometry. J. Obstet. Gynaec. Brit. Commonw. 81 (1974) 682

[8] MOLOY, H. C.: Studies of head molding during labor. Amer. J. Obstet. Gynec. 44 (1942) 762

[9] MYLES, M. D.: A Textbook for Midwives. E. and S. Livingston Ltd., London 1968

[10] POLL, V.: Precision of ultrasonic fetal cephalometry. Brit. J. Obstet. Gynaec. 83 (1976) 217

[11] REMINGTON, R. D., M. A. SCHORK: Statistics with Applications to the Biological and Health Sciences. Prentice-Hall, Inc., Englewood Cliffs, New Jersey 1970

[12] SCHWARZ, R. L., G. STRADA-SAENZ, O. ALTHABE, J. FERNANDEZ-FUNES, L. O:YÁLVAREZ, R. CALDEYRO-BARCIA: Compression received by the head of the human fetus during labor. In: Physical Trauma as an Etiological Agent in Mental Retar- 
dation. U.S. Department of Health, Education and Welfare, Washington, D.C. 1970

[13] STUMPF, M.: Beitrag zur Kenntnis der Beeinflussung der Kopfform durch die Geburtsvorgänge. Arch. Gynaek. 82 (1907) 215
[14] WILLERMAN, L.: Fetal head position during delivery and intelligence. In: Physical Trauma as an Etiological Agent in Mental Retardation. U.S. Department of Health, Education and Welfare, Washington, D.C. 1970

Received March 14, 1977. Accepted April 4, 1977.

Timothy J. Kriewall, Ph.D.

L-2011 Women's Hospital

University of Michigan Medical Center

Ann Arbor, Michigan 48109 U.S.A. 